\title{
'Invisible Obstacle' to Gender Equality: Gender Stereotype Messages in Early Childhood Education Books in Kenya
}

Juliet Njeri Muasya (Corresponding author)

School of Education, University of Nairobi

P. O. Box 30197-00100, Nairobi, Kenya

Tel: 254-724766431Ｅ-mail: julietnjerim@gmail.com

\author{
Ruth Mugo Kahiga \\ School of Education, University of Nairobi \\ P. O. Box 30197-00100, Nairobi, Kenya
}

Tel: 254-722704551Ｅ-mail: ruthwangu2007@yahoo.com

Received: April 29, 2018

doi:10.5296/gjes.v4i1.13074
Accepted: June 3, 2018

Published: June 12, 2018

URL: https://doi.org/10.5296/gjes.v4i1.13074

\begin{abstract}
Globally, research on gender stereotype messages or 'invisible obstacle' in the teaching and learning materials especially for primary and secondary schools is well documented. Findings from studies show illustrations, images, pictures and language that negatively portray males and females, boys and girls in learning materials and which tend to impact on students' behaviours, aspirations, experiences, participation, achievement and expectations. The aim of the current study was to find out how gender messages are portrayed in 10 purposively selected Science and English language Early Childhood Education course, supplementary and workbooks using a documentary analysis checklist. Findings from the current study reveal that although authors of the analysed books have to some extent made the books gender responsive, however, gender stereotype messages expressed in masculine and feminine discourses are still visible. Two series of the books analysed are gender blind. Use of gender responsive books is likely to help children appreciate each other's gender, thus, create more equitable learning outcomes. Thus, it is important that any gender stereotype messages or information in learning and teaching materials are dealt with during early years of a child's
\end{abstract}


life.

Keywords: Gender stereotype, Gender roles, Gender equality, Gender bias, Invisible obstacle 


\section{Introduction}

Gender bias in books remain pervasive or what Blumberg and Kenan (2015); 2015 UNESCO's Global Monitoring Report on Education for All refer to as 'invisible obstacle' to girl and female's equality in education and beyond. While reflecting on 'invisible obstacle', Gee and Gee (2005); Levtov (2014); Huntington (2013) noted that books, toys and other teaching materials continue to reinforce and uphold traditional gender stereotypes and inequalities, thus affects the effective implementation of a gender responsive curriculum. In particular, Beijing Declaration and Platform for Action 1995 states that: 'curricula and teaching materials remain gender-biased and are rarely sensitive to the needs of girls and boys; males and females'. Gender responsive curriculum materials have the potential of building knowledge and skills that support and promote children in discourses of dominant power structures; gender stereotypes and positive gender relations, thus, advancing the achievement of gender equality (Miske, 2013). The need to eliminate gender stereotype by revising books for inclusion is well articulated in international declarations, like Convention on Elimination of All Forms of Discrimination 1979, Convention on the Rights of the Child 1989 \& Dakar Framework for Action, Education for All 2000.

Gender stereotype and biased messages in teaching materials affect boys and girls in a variety of ways. For instance, it may impact on their self-esteem and image, aspirations, talents, abilities, expectations, behaviour, performance and expectations about life opportunities, career aspirations and prospects (Mirza, 2006; Esplen, 2009; Fousiya \& Musthafa, 2016). Thus, there is need to explore the nature of gendered messages in textbooks since any representation is likely to impact either negatively or positively on a child's development (Mustapha, 2012; Toci \& Aliu, 2013; Samadikhah \& Shahvokhi, 2015). Further, Gershuny (1997) in Samadikhah and Shahvokhi (2015) caution that gender bias in books may perpetuate children's negative roles and social values. The degree to which gender inequality, discrimination and stereotype messages are reinforced in books continue to put the girl child at a more disadvantaged position, at an early age (Abril, Cremers, Duncan, Golubevaite, Krabel, Lilaite, Nordfjell, Raudonyte \& Romero, 2008; Brugeilles \& Cromer, 2009). What this means is that gender sensitive books make boys and girls develop and learn socially constructed gender roles (Brugeilles \& Cromer, 2009; Karniol, 2011; Goble, Martin, Hanish $\&$ Fabes, 2012). Since books instill positive values and attitudes among children (Lee, 2011 in Mustapha, 2012), this could influence children's ideas and concepts about gender (Mirza, 2006; Aikman \& Rao, 2010).

Since the aim of any nation is to have an equal society, there is need to understand the nature and extent of gender bias since this informs people's thinking and behaviour in society (Mattu \& Hussain, 2004) including children. Mirza (2006); Blumberg and Kenan (2015) noted that in order to promote gender equality in education through policy reforms, there is need to first study learning materials, especially books for gender responsiveness and bias. A study of gender representation in textbooks is important because teachers and children spend about 80 per cent of their teaching and learning using textbooks (Jaber, 2014), thus books are a primary source of information (Toci \& Aliu, 2013). This means that any gender biased messages (images, illustrations, activities and language) in books could undermine 
gender sensitisation effort and development of appropriate programmes (Jaber, 2014) at all levels of education. By analysing ECE books for gender responsiveness, the findings will go a long way in guiding education stakeholders on how to prepare equitable curriculum materials, which could lead to achievement of equality, development and peace (Miske, 2013; Levtov, 2014; Tatengco, 2014).

The current research is partly based on recommendations by Miske (2013); Plan International (2013) who noted the need to find out the extent to which textbooks are gender responsive, in order to bring equitable learning outcomes for girls and boys. By conducting such a study it will be possible to know what girls and boys are learning about gender equality in schools (Winthrop \& McGivney, 2014). Specifically, the 2013 Task Force on Realignment of Education to 2010 Kenyan Constitution recommended review of textbooks and other educational materials in order to ensure enhancement of equal opportunities. In addition, Gender Policy in Education 2007 noted the need to review ECE curriculum materials, an important step towards making these materials gender sensitive, thus, facilitating the achievement of gender equality. Data from this study will inform early childhood teachers and other stakeholders the need to ensure that children are not exposed to gender biased books and especially, now (2018) when the 2:6:6:3 curriculum is being implemented in pre-primary 1, 2 and grades 1, 2 and 3 in Kenya. The purpose of this study was to find out the extent to which ECE books especially English language and Science are gender responsive.

\section{Literature Review}

A study done in primary schools in Pakistan by Mizra (2006) aimed at identifying gender disparities in curricula and textbooks for grades 1-X. About 194 textbooks in six subjects; English, Urdu, Science, Mathematics, Social Studies and Islamiat were reviewed for gender responsive messages. The findings show that majority of the books are gender insensitive, numerically and qualitatively biased towards males, where the characters of male and female are portrayed in gender stereotype messages. In Israel, Karniol (2011) presented 98 (4 to 8 year old) Jewish boys and girls with two colouring booklets. Karniol found that most boys and girls chose booklets with gender stereotypical characters on the cover. The choice of gender typed colours and figures, display ideas of what colours and images boys and girls perceive to be appropriate for each gender.

In 2012, Yang analysed New Magic, an English textbook series for primary schools in Hong Kong with the aim of finding out if gender stereotype is an issue. Yang used he/she, man/woman, boy/girl as categories for analysis. Findings show that authors of New Magic are aware of gender equality since the book has minimal gender stereotype messages. For instance, in domestic and occupational roles, females are not portrayed as housewives, but as doctors or school principals, while males are sharing household work with females at home. According to Yang (2012) portrayal of stereotype images is unavoidable because males and females are born to be physically different, thus, making them engage in different activities or do certain jobs. However, it is difficult to generalise Yang's findings because conclusions were drawn from one English textbook, New Magic.

In Macedonia, Toci and Aliu (2013) explored gender stereotype messages in three English 
textbooks, for beginners, pre-intermediate and intermediate level using professions, appearance, sports/hobbies, personality traits, family roles/housework as categories for analysis. Results of the study show that authors of English textbooks expose children to biased information when considering the professions of males and females. While females were portrayed more in traditional professional roles like nursing, teaching, hairdressing and flight attendants, males were presented as soccer players, waiters, pilots, securities, guitarists and astronauts. Authors of the textbooks tend to be deficient in knowledge about the effect of stereotypes in children's development. The unfair representation of gender characters is likely to make it difficult for children to effectively exploit their opportunities and abilities.

In their study, Jabeen, Chaudhary, and Omar (2014) assessed the magnitude and extent of gender stereotype of primary level (grade 1-5) English and national language (Urdu) books by Punjab Textbook Board. The content analysis was based on activities, roles, personality attributes, numbers, images and characters of males and females. The results reveal negative portrayal of female characters, while their stereotypical role is given in ways which depict illustrations that construct patriarchal culture and reinforcement of traditional gender roles in the textbooks. Female characters are invisible and the language used is based on stereotype thinking rather than on reality. Such negative information is likely to discourage girls from making appropriate choices and vision of what they could achieve in their personal and professional life (Jabeen et al., 2014).

In Jordan, Jaber (2014) examined direct and hidden gender bias in 38 primary pupil's textbooks and 12 teacher's guides for social studies, civic education, geography and vocational education by counting the images and illustrations of males and females. Jaber found that textbooks are written for males with emphasis on masculine norms which perpetuate gender bias. In addition, reference to engineers, doctors and laboratory technicians is presented in a masculine form while references to teachers and nurses are in feminine. Jaber's study did inform the current study on the need to use division of labour categories. Further, Tantengco (2014) assessed the extent to which gender equity is established in secondary school social studies curriculum in Phillippine. Results of the study show indicators of gender bias manifested in the learning environment, curriculum and instructional processes. Tantengco noted the need for textbook writers to make them gender sensitive by revising them.

In Iran Samadikhah and Shahrokhi (2015) evaluated gender representation in Top Notch and Summit series used in Iranian Language Institutes, while Fousiya and Musthafa (2016) did a study in Kerela state, India. Samadikhah and Shahrokhi (2015) aimed at finding out whether gender representation is equally balanced by using females and males characters; pictorial representations, titles, activities, firstness of females and males in mixed gender dialogues as categories for analysis. Through the use of critical discourse analysis, traces of gender representation tend to be more balanced in Top Notch than in Summit series. In collecting data, Fousiya and Musthafa (2016) used questionnaire, observation schedule and Focused Group Discussion to explore students' perceptions of gender in secondary school textbooks. Results from this study reveal that only $37 \%$ of students agree that textbooks depict stereotypical messages where males are shown as engineers, doctors, pilots, and lawyers, 


\section{$\triangle$ Macrothink}

Global Journal of Educational Studies

ISSN 2377-3936

2018, Vol. 4, No. 1

while females are represented as teachers, housewives, nurse to mention but a few. Further, it seems that instructional materials are dominated by stories, images, examples, voices of males, which show their dominance in the learning materials as compared to females. There is evidence to show that gender bias exist in school curriculum, which could affect career aspirations of the girl child. While Kerela's research was done in secondary schools, in the current study, researchers analysed ECE English Language and Science books for gender responsive messages. It is important to note that most of the studies reviewed used primary school textbooks and were done outside Kenya, except Karniol (2011); Toci and Aliu (2013) who analysed preschool books.

A comparative study done in Cameroon, Cote-d'Ivore, Togo and Tunisia; Brugeilles and Cromer (2009) analysed 24 mathematic textbooks to find out the nature of gender representations. The findings show that male characters are over represented, while female characters and role models are lacking. This continues to reinforce existing negative interest in mathematics especially among females and girls. If boys and girls, male and female teachers assimilate these negative messages, this could reinforce gender stereotype and discrimination in the society (Brugeilles \& Cromer, 2009). Kendall (2008) noted that it is critical that the learning materials communicate to girls and boys within the school environment positive messages, a way of enhancing achievement of gender equality.

In using English language and science books, the current study was further informed by Mizra (2006); Brugeilles and Cromer (2009); Mustapha (2012); Yang (2012); Toci and Aliu (2013); Jabeen, Chaudherg, and Omar (2014); Jaber (2014); Samadikhah and Shahrokhi (2015). For instance, Levtov (2014) noted that in mainstreaming gender into the curriculum, there is need to incorporate perspectives and experiences of boys and girls, discussion of gender roles and discrimination across the curriculum, particularly in science and language (literature), since they are core subjects in school curriculum. Science and language are economically and socially valued subjects in the society (Brugeilles \& Cromer, 2009). According to Toci and Aliu (2013) English language textbooks are considered to be major in most schools. In using books covering more than one subject, the research was further informed by Jaber (2014) who noted that since gender equality is multi-disciplinary, sometimes it becomes difficult to capture social, political and economic aspects effectively using one subject or discipline. Findings from the current study are more likely to provide reliable data that will help develop and design appropriate materials for ECE, especially now (2018) when the new system of education 2-6-6-3 is being rolled out to replace the old 8-4-4 system in Kenya.

Research on gender and ECE curriculum materials is scanty and limited in Kenya. However, a number of Kenyan scholars who have analysed primary and secondary school English language, Literature, History, Social Studies textbooks for gender responsiveness did inform the present study. In 1991 Obura explored the portrayal of girls and females in Kenyan textbooks using qualitative and quantitative data. Obura found that there were fewer, negative images of females, in relation to those of males. Further, Obura noted the frequent failure to name females, who appear subsequent to males on the page, in the paragraph, and within the sentence, lack female autonomy and emphasis on physical appearance rather than on 
achievement of females, which portray negative gender stereotype of girls and females. In Kitale, Foulds (2009) did a study done in three primary schools using content and situational analysis to examine the extent to which Kenyan social studies textbooks break through or reinforce gender stereotype messages. Foulds (2009) noted that authors and publishers of social studies textbooks have attempted to neutralise language in line with gender. There are indicators that females remain in homes and marginalised parts of Kenyan society. Although Fould's analysis is exclusively textual, it however, offers a strong foundation to enhance our understanding of the evolution of gender representation in textbooks in Kenya.

Kobia (2009) explored gender images in primary school English textbooks, 'Let's Learn English', and the findings reveal under-representation of female gender in author, editor, photographs and illustrations. Similarly, Gachara (2012) examined English literature textbooks for secondary schools using ABC Gender analysis model and Reader-Response Theory. Gachara's findings show elements of gender bias, stereotyping of character and role, unequal representation of male and female characters and use of gender insensitive language. In their research, Mburu and Nyaga (2012) analysed the effects of gender role portrayal using 40 primary school textbooks (Kiswahili, Mathematics, History and Civics) of class 1 to 3. Mburu and Nyaga found that gender stereotype impact on pupils academic aspirations since they tend to identify with characters of their gender portrayed in the textbooks. Mathuri, Ireri, Mukumi, Njagi, and Karugu (2012) analysed gender display in 40 selected children's picture books used as supplementary English language texts for class 1 to 3 and published between 2005 and 2010. In their conclusion, Mathuri et al (2012) noted that behaviour of female gender in children's books is significantly different from that of male gender.

Using four secondary school New Integrated English textbooks, Malova's (2012) aim was to examine the extent to which these textbooks are gender biased using visibility, authorship, firstness in dialogues, generic masculine constructions, sex-linked occupations and activities. Malova's findings reveal under-representation of males as authors, content dominated by male which portrays patriarchal culture in the society, and that males outnumber females in photographs. In some of the books there is gender inclusive, neutral and sensitive language. Although males and females are involved in productive and reproductive roles, most of the reproductive roles like cooking, washing, visiting, collecting firewood and cleaning were done by females. Females are stereotyped as stay at home mothers engaged in household chores, whereas males are involved in reading newspapers, fixing car, swimming or looking for jobs. Malova's study did inform the current study on the need to classify activities into productive, reproductive, in addition to leisure activities, as categories for analysis. Reviewed literature from Kenya so far shows that most of the studies on gender representation have been done using primary and secondary school books as shown by Foulds (2009); Kobia (2009); Mburu and Nyaga (2012); Mathuri et al. (2012); Gachara (2012); Malova (2012). There is lack of information in regard to gender and ECE books in Kenya. Most of the studies done in Kenya have used English language textbooks, which further informed the present study on the books to use for the analysis of gender responsive messages. The current study is further informed by Miske (2013) who noted that review of gender insensitive curriculum and support materials usually result in changes likely to provide teachers with a gender equitable 
curriculum and textbooks.

\section{Methodology}

This is a desktop research based on quantitative and qualitative analysis of 10 purposively selected Science and English language ECE books under the National Centre for Early Childhood Education (NACECE) and District Centres for Early Childhood Education (DICECE) curriculum. Sampling of books for analysis in this study was guided by the Orange book which has the list of approved school textbooks and other instructional materials by the Ministry of Education, Science \& Technology (2016) for ECE, primary schools and primary teacher training colleges. These materials are vetted by the Kenya Institute of Curriculum Development (KICD) to ensure quality and acceptable standards. In reference to the Orange book and in consultation with major bookshop outlets (Textbook centre) and for the purposes of this study, the type of books analysed were 5 workbooks, 3 supplementary and 2 workbooks.

Table 1. List of english language and science books

\begin{tabular}{|c|c|c|c|c|c|}
\hline $\begin{array}{c}\text { Activity } \\
\text { areas }\end{array}$ & Title & Author & Publisher & $\begin{array}{c}\text { Year } \\
\text { published }\end{array}$ & Code \\
\hline $\begin{array}{c}\text { English } \\
\text { Language }\end{array}$ & The Big Step & $\begin{array}{c}\text { Gatua, C. Kagasi, M. } \\
\text { Njoroge, M. \& Omondi, C. }\end{array}$ & Oxford & 2009 & D1L \\
\hline $\begin{array}{c}\text { English } \\
\text { Language }\end{array}$ & Tip Top & Muthoni, A. & Mountain Top & 2010 & D2L \\
\hline $\begin{array}{c}\text { English } \\
\text { Language }\end{array}$ & Day to Day & None & Moran & None & D3L \\
\hline $\begin{array}{c}\text { English } \\
\text { Language }\end{array}$ & Little Birds & Mogaka, F. \& Ronoh, J.C. & Longhorn & 2014 & D4L \\
\hline $\begin{array}{c}\text { English } \\
\text { Language }\end{array}$ & Alpha & Rop, D.K \& Kiburi, O.K. & Kenya Literature \\
Bureau & 2013 & D5L \\
\hline $\begin{array}{c}\text { Science } \\
\text { Alpha }\end{array}$ & Rop, D.K \& Kiburi, O.K & Kenya Literature \\
Bureau & 2013 & D1S \\
\hline Science & Tip Top & Muthoni, A. & Mountain Top & 2010 & D2S \\
\hline Science & Day to Day & None & Moran & None & D3S \\
\hline Science & Little Birds & Mogaka, F. \& Ronoh, J.C. & Longhorn & 2014 & D4S \\
\hline Science & The Big Step & $\begin{array}{c}\text { Gatua, C. Kagasi, M. } \\
\text { Njoroge, M. \& Omondi, C. }\end{array}$ & Oxford & 2009 & D5S \\
\hline
\end{tabular}

Table 1 shows the specific types and titles of books analysed in this study. The documentary analysis checklist used in this study was developed and modified to fit the Kenyan preschool context using gender analysis frameworks by Obura (1991); Kabira and Masinjila (1997); Brugeilles and Cromer (2009). With a documentary analysis checklist, it was possible to examine gendered messages in form of pictures and activities presented in selected $10 \mathrm{ECE}$ 
books. To be able to map out the hidden gender stereotype messages or 'invisible obstacle', from 10 ECE books, the following categories were used; authors, pictorial representation and activities assigned to male, female, boy and girl child. The activities were further categorised into productive activity (PA): (PA1 medical, PA2 school; PA3 agricultural; PA4 construction; PA5 transport; PA6 security; PA7 political; PA8 Religious; PA9 other economic activities; PA10 hygienic); RA (reproductive) and LA (leisure). A documentary checklist give visual representation of the occurrences of negative and positive messages representing male and female, boys and girls in a book (Jaber, 2014). In analysing data collected through documentary analysis checklist, the coded information was entered into a spread sheet using gender of the author, picture representation and activities done by each gender (male, female, girl and boy). Data in the spread sheet was further analysed through the SPSS version 20.0 and excel stata to generate descriptive statistics in form of frequencies and percentages. The data was presented in tables and graphs, in addition to interpretation and discussion of the findings.

\section{Presentation of Research Findings}

\subsection{Authors of Selected Early Childhood Education Books by Gender}

The study sought to find out the gender of authors of the analysed ECE books.

Table 2. Gender of the authors

\begin{tabular}{ccccccccccc}
\hline Author & \multicolumn{4}{c}{ Science } & \multicolumn{7}{c}{ Language } \\
\cline { 2 - 12 } & D1S & D2S & D3S & D4S & D5S & D1L & D2L & D3L & D4L & D5L \\
\hline Male & 1 & 0 & 0 & 1 & 1 & 1 & 0 & 0 & 0 & 0 \\
Female & 2 & 1 & 0 & 1 & 3 & 2 & 1 & 0 & 1 & 2 \\
\hline Total & 3 & 1 & 0 & 2 & 4 & 3 & 1 & 0 & 1 & 2 \\
\hline
\end{tabular}

The information presented in Table 2 shows the gender of authors of the ECE materials analysed in this study. Data analysed reveal that majority of authors of ECE books are females. D5S (The Big Step S) had the highest number of authors, 3 females and 1 male, while D1S (Alpha S), DIL (The Big Step L) had 2 females and 1 male author each. It is surprising that there were no authors for the D3S (Day to Day S) and D3L (Day to Day L); the question is who wrote these books? Overall, it seems that female gender (13) is better represented across the books analysed as compared to male (4) authors. In particular, there are more female authors (7) in science books, as compared to (3) male authors. Although Malova (2012)'s findings concurs with those of the current study regarding the under-representation of male authors in four secondary school English textbooks, the findings further contradict those by Kobia (2009) who reported under-representation of female gender as authors in 'Lets Learn English' a primary school textbook. The question remains: does the gender of the author influence the type of pictures/illustrations in selected ECE books in terms of gender? 
4.2 Pictorial Representation in Selected Science and English Language Books by Gender

Table 3. Representation of pictures by gender

\begin{tabular}{lcccccccc}
\hline Title of Books & \multicolumn{2}{c}{ Male } & \multicolumn{2}{c}{ Female } & \multicolumn{3}{c}{ Girl } & \multicolumn{3}{c}{ Boy } \\
\cline { 2 - 9 } & F & $\%$ & F & $\%$ & F & $\%$ & F & $\%$ \\
\hline Alpha (S) & 14 & 7.3 & 5 & 2.4 & 72 & 14.5 & 75 & 15.0 \\
Tip Top (S) & 4 & 1.7 & 5 & 2.4 & 5 & 1.0 & 7 & 1.4 \\
Day to Day (S) & 8 & 3.4 & 3 & 1.4 & 44 & 8.8 & 45 & 9.0 \\
Little Birds (S) & 0 & 0.0 & 0 & 0.0 & 13 & 2.6 & 16 & 3.2 \\
The Big Step (S) & 14 & 6.0 & 5 & 2.5 & 72 & 14.5 & 75 & 15.0 \\
The Big Step (L) & 40 & 17.2 & 46 & 21.7 & 54 & 10.8 & 43 & 8.6 \\
Tip Top (L) & 25 & 10.7 & 22 & 10.4 & 22 & 4.4 & 25 & 5.0 \\
Day to Day (L) & 23 & 9.9 & 25 & 11.8 & 17 & 3.4 & 26 & 5.2 \\
Little Birds (L) & 4 & 1.7 & 0 & 0.0 & 0 & 0.0 & 4 & 0.8 \\
Alpha (L) & 54 & 23.2 & 64 & 30.2 & 51 & 10.2 & 37 & 7.4 \\
\hline
\end{tabular}

Table 3 shows more pictures of girls and boys represented in science books, especially in Alpha (S), Day to Day (S) and The Big Step (S) as compared to males and females. Specifically, in Alpha (S) and The Big Step (S), the picture representation of girls and boys is similar, that is $72(14.5 \%)$ and $75(15.0 \%)$ respectively. Similarily, in The Big Step (L) and Alpha (L) there is a better coverage of gender representation of pictures as compared to Tip Top (L), Day to Day (L) and Little Birds (L) as shown in Table 3. It seems that gender of the authors is likely to influence the representation of illustrations in the books by gender. While the picture representation by gender in the current study concurs with the findings of Samadikhah and Shahrokhi (2015), the findings further contradicts those by Jabeen, et.al (2014) who noted that characters of female are invisible. Any fair gender representation in textbooks encourage girls and boys to expand the choice and vision of their personal and professional life (Jabeen et al., 2014) which is likely to facilitate achievement of gender equality.

\subsection{Activities in Selected Science and English Language Books by Gender}

In analysing science and English language books for gender representation of activities, use of productive, reproductive and leisure categories was informed by Malova (2012); Jaber (2014). In particular, Jaber (2014) noted that use of division of labour categories help generate difference in occupations suitable to males and females, girls and boys.

\subsubsection{Science Books}


Table 4a. Alpha (Science)

\begin{tabular}{llcccccccc}
\hline Type of Activities & & \multicolumn{2}{c}{ Male } & \multicolumn{2}{c}{ Female } & \multicolumn{3}{c}{ Boy } & \multicolumn{2}{c}{ Girl } \\
\cline { 2 - 10 } & & $\mathrm{F}$ & $\%$ & $\mathrm{~F}$ & $\%$ & $\mathrm{~F}$ & $\%$ & $\mathrm{~F}$ & $\%$ \\
\hline Productive & PA1 & 0 & 0.0 & 0 & 0.0 & 0 & 0.0 & 0 & 0.0 \\
& PA2 & 0 & 0.0 & 1 & 33.33 & 1 & 50.0 & 0 & 0.0 \\
& PA3 & 1 & 20.0 & 0 & 0.0 & 0 & 0.0 & 1 & 33.33 \\
& PA4 & 0 & 0.0 & 0 & 0.0 & 0 & 0.0 & 0 & 0.0 \\
& PA5 & 0 & 0.0 & 0 & 0.0 & 0 & 0.0 & 0 & 0.0 \\
& PA6 & 1 & 20.0 & 0 & 0.0 & 0 & 0.0 & 0 & 0.0 \\
& PA7 & 0 & 0.0 & 0 & 0.0 & 0 & 0.0 & 0 & 0.0 \\
& PA8 & 0 & 0.0 & 0 & 0.0 & 0 & 0.0 & 0 & 0.0 \\
Leisure & PA9 & 1 & 20.0 & 1 & 33.33 & 0 & 0.0 & 0 & 0.0 \\
Reproductive & PA10 & 0 & 0.0 & 0 & 0.0 & 0 & 0.0 & 0 & 0.0 \\
\hline Total & LA & 1 & 20.0 & 0 & 0.0 & 0 & 0.0 & 1 & 33.33 \\
& RA & 1 & 20.0 & 1 & 33.33 & 1 & 50.0 & 1 & 33.33 \\
\hline
\end{tabular}

Information from Table 4a shows that in Alpha (science) book, females, males, boys and girls are represented in PA2 (school), PA3 (agriculture), PA9 (other economic), LA (leisure) and RA (reproductive) activities. Notably, females are represented as teachers, whereas boys are engaged in outdoor and indoor activities for instance reading, weighing and balancing, blowing bubbles and climbing (PA2). In particular, girls are taking care of animals, grazing goats, cows and feeding chicken and rabbits, watering plants, while males are involved in digging, milking, cultivating, fishing and spraying cows and plants (PA3). Of concern and as part of their LA, males are playing with guitar, trumpet, whistle, in addition to taking care of animals (rhino, monkeys, lion) in the zoo. Girls and females are for instance, involved in cutting papaws, bathing the baby, washing utensils, while boys are washing clothes (RA).

Table 4b. Tip top (Science)

\begin{tabular}{llcccccccc}
\hline Type of Activities & & \multicolumn{2}{c}{ Male } & \multicolumn{2}{c}{ Female } & \multicolumn{3}{c}{ Boy } & \multicolumn{2}{c}{ Girl } \\
\cline { 3 - 10 } & & $\mathrm{F}$ & $\%$ & $\mathrm{~F}$ & $\%$ & $\mathrm{~F}$ & $\%$ & $\mathrm{~F}$ & $\%$ \\
\hline Productive & PA1 & 0 & 0.0 & 0 & 0.0 & 0 & 0.0 & 0 & 0.0 \\
& PA2 & 0 & 0.0 & 0 & 0.0 & 0 & 0.0 & 0 & 0.0 \\
& PA3 & 1 & 100.0 & 1 & 100.0 & 1 & 100.0 & 1 & 100.0 \\
& PA4 & 0 & 0.0 & 0 & 0.0 & 0 & 0.0 & 0 & 0.0 \\
& PA5 & 0 & 0.0 & 0 & 0.0 & 0 & 0.0 & 0 & 0.0 \\
& PA6 & 0 & 0.0 & 0 & 0.0 & 0 & 0.0 & 0 & 0.0 \\
& PA7 & 0 & 0.0 & 0 & 0.0 & 0 & 0.0 & 0 & 0.0 \\
& PA8 & 0 & 0.0 & 0 & 0.0 & 0 & 0.0 & 0 & 0.0 \\
Leisure & PA9 & 0 & 0.0 & 0 & 0.0 & 0 & 0.0 & 0 & 0.0 \\
Reproductive & PA10 & 0 & 0.0 & 0 & 0.0 & 0 & 0.0 & 0 & 0.0 \\
\hline Total & LA & 0 & 0.0 & 0 & 0.0 & 0 & 0.0 & 0 & 0.0 \\
\hline & RA & 0 & 0.0 & 0 & 0.0 & 0 & 0.0 & 0 & 0.0 \\
\hline
\end{tabular}


Data in Table 4b shows that gender representation of activities in Tip Top (science) book mostly cover PA3 (agricultural) and is visible across females, males, boys and girls. Males are seen feeding chicken, while females are taking care of domestic animals. Watering plants is an activity seen to be done by males and females, girls and boys. However, the book is gender blind or neutral, which means that it distinguishes little between the need of males, females, girls and boys, thus, it neither reinforces nor questions gender roles or activities.

Table 4c. Day to Day (Science)

\begin{tabular}{|c|c|c|c|c|c|c|c|c|c|}
\hline \multirow[t]{2}{*}{ Type of Activities } & & \multicolumn{2}{|c|}{ Male } & \multicolumn{2}{|c|}{ Female } & \multicolumn{2}{|c|}{ Boy } & \multicolumn{2}{|c|}{ Girl } \\
\hline & & $\mathrm{F}$ & $\%$ & $\mathrm{~F}$ & $\%$ & $\mathrm{~F}$ & $\%$ & $\mathrm{~F}$ & $\%$ \\
\hline \multirow[t]{10}{*}{ Productive } & PA1 & 0 & 0.0 & 0 & 0.0 & 0 & 0.0 & 0 & 0.0 \\
\hline & PA2 & 0 & 0.0 & 1 & 33.33 & 1 & 33.33 & 1 & 33.33 \\
\hline & PA3 & 0 & 0.0 & 0 & 0.0 & 0 & 0.0 & 0 & 0.0 \\
\hline & PA4 & 0 & 0.0 & 0 & 0.0 & 0 & 0.0 & 0 & 0.0 \\
\hline & PA5 & 1 & 50.0 & 0 & 0.0 & 0 & 0.0 & 0 & 0.0 \\
\hline & PA6 & 0 & 0.0 & 0 & 0.0 & 0 & 0.0 & 0 & 0.0 \\
\hline & PA7 & 0 & 0.0 & 0 & 0.0 & 0 & 0.0 & 0 & 0.0 \\
\hline & PA8 & 0 & 0.0 & 0 & 0.0 & 0 & 0.0 & 0 & 0.0 \\
\hline & PA9 & 0 & 0.0 & 0 & 0.0 & 0 & 0.0 & 0 & 0.0 \\
\hline & PA10 & 0 & 0.0 & 1 & 33.33 & 0 & 0.0 & 0 & 0.0 \\
\hline Leisure & LA & 0 & 0.0 & 0 & 0.0 & 0 & 0.0 & 0 & 0.0 \\
\hline Reproductive & RA & 1 & 50.0 & 1 & 33.33 & 0 & 0.0 & 0 & 0.0 \\
\hline Total & & 2 & 100.0 & 3 & 100.0 & 1 & 100.0 & 1 & 100.0 \\
\hline
\end{tabular}

As shown in Table 4c, boys, girls and females represented in Day to Day (science) book are engaged in PA2 (school), PA10 (hygiene) and RA (reproductive), while males are more visible in RA (reproductive) and PA5 (transport) activities. Boys and girls are engaged in PA2 (school), for instance, they are weighing and balancing activities, using a bucket and water, playing with ball, swinging, pulling a rope, while the boy child is playing with tyre. In PA5 (transport), there is a picture of a male pulling a cart, while in RA (reproductive) a boy is seen hanging clothes.

Table 4d. Little birds (Science)

\begin{tabular}{lccccccccc}
\hline Type of Activities & & \multicolumn{2}{c}{ Male } & \multicolumn{2}{c}{ Female } & \multicolumn{3}{c}{ Boy } & \multicolumn{2}{c}{ Girl } \\
\cline { 2 - 10 } & & $\mathrm{F}$ & $\%$ & $\mathrm{~F}$ & $\%$ & $\mathrm{~F}$ & $\%$ & $\mathrm{~F}$ & $\%$ \\
\hline Productive & PA1 & 0 & 0.0 & 0 & 0.0 & 0 & 0.0 & 0 & 0.0 \\
& PA2 & 0 & 0.0 & 0 & 0.0 & 1 & 50.0 & 1 & 50.0 \\
& PA3 & 1 & 25.0 & 0 & 0.0 & 1 & 50.0 & 0 & 0.0 \\
& PA4 & 0 & 0.0 & 0 & 0.0 & 0 & 0.0 & 0 & 0.0 \\
& PA5 & 1 & 25.0 & 0 & 0.0 & 0 & 0.0 & 0 & 0.0 \\
& PA6 & 1 & 25.0 & 0 & 0.0 & 0 & 0.0 & 0 & 0.0 \\
& PA7 & 0 & 0.0 & 0 & 0.0 & 0 & 0.0 & 0 & 0.0 \\
& PA8 & 0 & 0.0 & 0 & 0.0 & 0 & 0.0 & 0 & 0.0 \\
Leisure & PA9 & 0 & 0.0 & 0 & 0.0 & 0 & 0.0 & 0 & 0.0 \\
Reproductive & PA10 & 0 & 0.0 & 0 & 0.0 & 1 & 25.0 & 1 & 25.0 \\
Total & LA & 0 & 0.0 & 0 & 0.0 & 1 & 25.0 & 1 & 25.0 \\
\hline
\end{tabular}




\section{$\triangle$ Macrothink}

In Table $4 \mathrm{~d}$ there are more males and boys in Little Birds (S) book engaged in PA2 (school), PA3 (agricultural), PA5 (transport), PA6 (security) and RA (reproductive) activities as compared to females and girls. For instance, there are three males, one is carrying a heavy log, the other one is pushing a car (PA5), while the third one is playing the role of a watchman (PA6). In a different picture a female (mother) is seen cooking/smelling food. Both girls and boys are seen participating in PA3 and PA10, for instance playing with kites, ball, hide and seek games, while others are at home listening to the radio (LA).

Table 4e. The big step (Science)

\begin{tabular}{llcccccccc}
\hline Type of Activities & & \multicolumn{2}{c}{ Male } & \multicolumn{2}{c}{ Female } & \multicolumn{3}{c}{ Boy } & \multicolumn{2}{c}{ Girl } \\
\cline { 2 - 10 } & & $\mathrm{F}$ & $\%$ & $\mathrm{~F}$ & $\%$ & $\mathrm{~F}$ & $\%$ & $\mathrm{~F}$ & $\%$ \\
\hline Productive & PA1 & 1 & 20.0 & 0 & 0.0 & 1 & 25.0 & 1 & 25.0 \\
& PA2 & 1 & 20.0 & 1 & 20.0 & 1 & 25.0 & 1 & 25.0 \\
& PA3 & 1 & 20.0 & 1 & 20.0 & 0 & 0.0 & 0 & 0.0 \\
& PA4 & 0 & 0.0 & 0 & 0.0 & 0 & 0.0 & 0 & 0.0 \\
& PA5 & 1 & 20.0 & 0 & 0.0 & 1 & 25.0 & 1 & 25.0 \\
& PA6 & 0 & 0.0 & 0 & 0.0 & 0 & 0.0 & 0 & 0.0 \\
& PA7 & 1 & 20.0 & 1 & 20.0 & 0 & 0.0 & 0 & 0.0 \\
& PA8 & 0 & 0.0 & 0 & 0.0 & 0 & 0.0 & 0 & 0.0 \\
Leisure & PA9 & 0 & 0.0 & 0 & 0.0 & 0 & 0.0 & 0 & 0.0 \\
Reproductive & PA10 & 0 & 0.0 & 0 & 0.0 & 0 & 0.0 & 0 & 0.0 \\
\hline Total & LA & 0 & 0.0 & 1 & 0.0 & 1 & 25.0 & 1 & 25.0 \\
\hline
\end{tabular}

Although data from Table 4e drawn from analysis of The Big Step book, which is authored by three females and one male shows an improved gender representation of different activities, there are a number of gender stereotyped activities. All boys, girls, males and females in this book are shown participating in PA2 (school). For instace, boys and girls are blowing balloons, running, and modelling with clay, while the teacher is portrayed as a female in the classroom and a male teacher is carrying out experiments in the laboratory. A male is shown engaged in PA1 (medical), and in particular veterinary doctor. Males and females are engaged in PA3 (agricultural), for instance digging and cultivating, while boys and girls in LA (leisure), particularly swimming. In addition, males are pushing and pulling a car stuck in the mud in PA5 (transport). 


\subsubsection{English Language Books}

Table 4f. The big step (Language)

\begin{tabular}{llcccccccc}
\hline Type of Activities & & \multicolumn{2}{c}{ Male } & \multicolumn{2}{c}{ Female } & \multicolumn{3}{c}{ Boys } & \multicolumn{2}{c}{ Girls } \\
\cline { 2 - 10 } & & F & $\%$ & F & $\%$ & F & $\%$ & F & $\%$ \\
\hline Productive & PA1 & 1 & 12.5 & 1 & 16.67 & 0 & 0.0 & 0 & 0.0 \\
& PA2 & 1 & 12.5 & 1 & 16.67 & 1 & 50.0 & 0 & 0.0 \\
& PA3 & 1 & 12.5 & 1 & 16.67 & 0 & 0.0 & 1 & 33.33 \\
& PA4 & 1 & 12.5 & 0 & 0.0 & 0 & 0.0 & 0 & 0.0 \\
& PA5 & 0 & 0.0 & 0 & 0.0 & 0 & 0.0 & 0 & 0.0 \\
& PA6 & 1 & 12.5 & 1 & 16.67 & 0 & 0.0 & 0 & 0.0 \\
& PA7 & 0 & 0.0 & 0 & 0.0 & 0 & 0.0 & 0 & 0.0 \\
& PA8 & 0 & 0.0 & 0 & 0.0 & 0 & 0.0 & 0 & 0.0 \\
Leisure & PA9 & 1 & 12.5 & 0 & 0.0 & 0 & 0.0 & 0 & 0.0 \\
Reproductive & PA10 & 0 & 0.0 & 0 & 0.0 & 0 & 0.0 & 0 & 0.0 \\
Total & LA & 1 & 12.5 & 1 & 16.67 & 1 & 50.0 & 1 & 33.33 \\
\hline & RA & 1 & 12.5 & 1 & 16.67 & 0 & 0.0 & 1 & 33.3 \\
\hline
\end{tabular}

Like was the case with The Big Step (science), there seem to be an improved gender representation in The Big Step (Language) especially in activities done by males, females, boys and girls PA1 (medical), PA2 (school), PA3 (agriculture), PA6( security), PA9 (other economic activities), RA (reproductive) and LA (leisure) as shown in Table 4f. However, although females are depicted as head teachers and teachers (PA2), selling cereals (PA9), nurse and pharmacists (PA1), male pictures are shown as doctors (PA1), training a dog (PA6), chef, fishing and riding a camel (PA5), while girls and boys are more visible in PA2, for instance, planting while in LA, children are admiring themselves in the mirror.

Table 4g. Tip top (Language)

\begin{tabular}{lccccccccc}
\hline Type of Activities & & \multicolumn{2}{c}{ Male } & \multicolumn{2}{c}{ Female } & \multicolumn{2}{c}{ Boy } & \multicolumn{2}{c}{ Girl } \\
\cline { 2 - 10 } & & F & $\%$ & F & $\%$ & F & $\%$ & F & $\%$ \\
\hline Productive & PA1 & 1 & 33.33 & 1 & 25.0 & 0 & 0.0 & 0 & 0.0 \\
& PA2 & 0 & 0.0 & 0 & 0.0 & 1 & 33.33 & 1 & 33.33 \\
& PA3 & 0 & 0.0 & 1 & 25.0 & 1 & 33.33 & 1 & 33.33 \\
& PA4 & 0 & 0.0 & 0 & 0.0 & 0 & 0.0 & 0 & 0.0 \\
& PA5 & 0 & 0.0 & 0 & 0.0 & 0 & 0.0 & 0 & 0.0 \\
& PA6 & 0 & 0.0 & 0 & 0.0 & 0 & 0.0 & 0 & 0.0 \\
& PA7 & 0 & 0.0 & 0 & 0.0 & 0 & 0.0 & 0 & 0.0 \\
& PA8 & 0 & 0.0 & 0 & 0.0 & 0 & 0.0 & 0 & 0.0 \\
Leisure & PA9 & 1 & 33.33 & 1 & 25.0 & 0 & 0.0 & 0 & 0.0 \\
Reproductive & PA10 & 0 & 0.0 & 0 & 0.0 & 1 & 33.33 & 1 & 33.33 \\
Total & LA & 0 & 0.0 & 0 & 0.0 & 0 & 0.0 & 0 & 0.0 \\
\hline & RA & 1 & 0.0 & 1 & 0.0 & 1 & 0.0 & 1 & 0.0 \\
\hline
\end{tabular}




\section{Macrothink}

Global Journal of Educational Studies

ISSN 2377-3936 2018, Vol. 4, No. 1

As shown in Table $4 \mathrm{~g}$, there are more representation of males and females engaged in PA1 (medical), PA3 (agriculture), PA9 (other economic activities), as compared to boys and girls who are more represented in PA2 (school) and PA (10). For instance, the nurses are depicted as females, while doctor is a male (PA1), and there are more females buying and selling in the market as compared to males, boys and girls (PA9). Females are feeding chicken, while girls and boys are taking care of domestic animals, for instance, cattle, sheep and pigs (PA3).

Table 4h. Day to day (Language)

\begin{tabular}{llcccccccc}
\hline Type of Activities & & \multicolumn{2}{c}{ Male } & \multicolumn{2}{c}{ Female } & \multicolumn{2}{c}{ Boy } & \multicolumn{2}{c}{ Girl } \\
\cline { 2 - 10 } & & $\mathrm{F}$ & $\%$ & $\mathrm{~F}$ & $\%$ & $\mathrm{~F}$ & $\%$ & $\mathrm{~F}$ & $\%$ \\
\hline Productive & PA1 & 1 & 12.5 & 1 & 20.0 & 0 & 0.0 & 0 & 0.0 \\
& PA2 & 1 & 12.5 & 1 & 20.0 & 1 & 33.33 & 1 & 33.33 \\
& PA3 & 1 & 12.5 & 0 & 0.0 & 1 & 33.33 & 1 & 33.33 \\
& PA4 & 0 & 0.0 & 0 & 0.0 & 0 & 0.0 & 0 & 0.0 \\
& PA5 & 1 & 12.5 & 0 & 0.0 & 0 & 0.0 & 0 & 0.0 \\
& PA6 & 1 & 12.5 & 0 & 0.0 & 0 & 0.0 & 0 & 0.0 \\
& PA7 & 1 & 12.5 & 0 & 0.0 & 0 & 0.0 & 0 & 0.0 \\
& PA8 & 1 & 12.5 & 1 & 20.0 & 0 & 0.0 & 0 & 0.0 \\
Leisure & PA9 & 1 & 12.5 & 1 & 20.0 & 0 & 0.0 & 0 & 0.0 \\
Reproductive & PA10 & 0 & 0.0 & 0 & 0.0 & 0 & 0.0 & 0 & 0.0 \\
Total & LA & 0 & 0.0 & 0 & 0.0 & 1 & 33.33 & 1 & 33.33 \\
\hline & RA & 0 & 0.0 & 1 & 20.0 & 0 & 0.0 & 0 & 0.0 \\
\hline
\end{tabular}

Information in Table $4 \mathrm{~h}$ in the Day to Day (language) book shows more males and females are represented in PA1 (medical), PA3 (agriculture), PA5 (transport), PA6 (security), PA8 (religious) and PA9 (other economic activities) as compared to girls and boys. Of particular significant is in PA1, where nurses continue to be portrayed as females and doctor as males, as was the case in The Big Step (Science) and Tip Top (Language) books. Males are represented as security guards and police officers (PA6). In the Day to Day (Language) book, males are shown as clergy or pastors (PA8), a unique activity, as compared to activities in other language books (The Big Step and Tip Top). 
Table 4i. Little birds (Language)

\begin{tabular}{lccccccccc}
\hline Type of Activities & & \multicolumn{2}{c}{ Male } & \multicolumn{2}{c}{ Female } & \multicolumn{3}{c}{ Boy } & \multicolumn{2}{c}{ Girl } \\
\cline { 3 - 10 } & & $\mathrm{F}$ & $\%$ & $\mathrm{~F}$ & $\%$ & $\mathrm{~F}$ & $\%$ & $\mathrm{~F}$ & $\%$ \\
\hline Productive & PA1 & 0 & 0.0 & 0 & 0.0 & 0 & 0.0 & 0 & 0.0 \\
& PA2 & 0 & 0.0 & 0 & 0.0 & 1 & 100.0 & 1 & 100.0 \\
& PA3 & 0 & 0.0 & 0 & 0.0 & 0 & 0.0 & 0 & 0.0 \\
& PA4 & 0 & 0.0 & 0 & 0.0 & 0 & 0.0 & 0 & 0.0 \\
& PA5 & 0 & 0.0 & 0 & 0.0 & 0 & 0.0 & 0 & 0.0 \\
& PA6 & 0 & 0.0 & 0 & 0.0 & 0 & 0.0 & 0 & 0.0 \\
& PA7 & 0 & 0.0 & 0 & 0.0 & 0 & 0.0 & 0 & 0.0 \\
& PA8 & 0 & 0.0 & 0 & 0.0 & 0 & 0.0 & 0 & 0.0 \\
& PA9 & 0 & 0.0 & 0 & 0.0 & 0 & 0.0 & 0 & 0.0 \\
Leisure & PA10 & 0 & 0.0 & 0 & 0.0 & 0 & 0.0 & 0 & 0.0 \\
Reproductive & LA & 0 & 0.0 & 0 & 0.0 & 0 & 0.0 & 0 & 0.0 \\
\hline Total & RA & 0 & 0.0 & 0 & 0.0 & 0 & 0.0 & 0 & 0.0 \\
\hline
\end{tabular}

Information in Table 4i show gender representation in only PA2 (school) a contrast with Little Bird (science), which covers activities such as: PA2 (school), PA3 (agriculture), PA5 (transport), PA6 (security), PA10 (hygiene), LA (leisure) and RA (reproductive), yet the two books are written by same author. Two of the books, Little Birds (language) and Tip Top (science) (see Table 4b) are gender blind or neutral in terms of content and illustrations.

Table 4j. Alpha (Language)

\begin{tabular}{llcccccccc}
\hline Type of Activities & & \multicolumn{2}{c}{ Male } & \multicolumn{2}{c}{ Female } & \multicolumn{2}{c}{ Boy } & \multicolumn{2}{c}{ Girl } \\
\cline { 3 - 9 } & & $\mathrm{F}$ & $\%$ & $\mathrm{~F}$ & $\%$ & $\mathrm{~F}$ & $\%$ & $\mathrm{~F}$ & $\%$ \\
\hline Productive & PA1 & 1 & 12.5 & 1 & 25.0 & 0 & 0.0 & 0 & 0.0 \\
& PA2 & 0 & 0.0 & 1 & 25.0 & 0 & 0.0 & 0 & 0.0 \\
& PA3 & 1 & 12.5 & 0 & 0.0 & 0 & 0.0 & 0 & 0.0 \\
& PA4 & 1 & 12.5 & 0 & 0.0 & 0 & 0.0 & 0 & 0.0 \\
& PA5 & 1 & 12.5 & 1 & 25.0 & 0 & 0.0 & 0 & 0.0 \\
& PA6 & 1 & 12.5 & 0 & 0.0 & 0 & 0.0 & 0 & 0.0 \\
& PA7 & 1 & 12.5 & 0 & 0.0 & 0 & 0.0 & 0 & 0.0 \\
& PA8 & 0 & 0.0 & 0 & 0.0 & 0 & 0.0 & 0 & 0.0 \\
Leisure & PA9 & 1 & 12.5 & 0 & 0.0 & 0 & 0.0 & 0 & 0.0 \\
Reproductive & PA10 & 0 & 0.0 & 0 & 0.0 & 0 & 0.0 & 0 & 0.0 \\
\hline Total & LA & 1 & 12.5 & 0 & 0.0 & 0 & 0.0 & 0 & 0.0 \\
\hline
\end{tabular}

Results from Table $4 \mathrm{j}$ shows males are more depicted in the productive, reproductive and leisure activities as compared to females, girls and boys. In a unique way as compared to other books, in Alpha (language) males are engaged in PA9 as school chef, shoemakers, barber and selling in butchery, PA1 as laboratory attendant, PA6 as security guard, in PA7 as a president 
addressing a public meeting. It is significant to note that under PA5 a female is seen carrying a luggage on her head, while two males are doing the same activity using a bicycle and a cart. A female is shown driving a bus (PA5), while another one is engaged in routine activities of bathing a baby (RA).

\section{Discussion of the Findings}

Although there is gender inclusive, neutral and sensitive language in almost all the 10 ECE Science and English language books analysed, findings similar to studies done by Yang (2012); Malova (2012); Samadikhah and Shahrokhi (2015), there are indicators which show gender biased activities assigned to females, males, boys and girls in some of the books. For instance, laboratory attendants, doctors, pushing and pulling of cars, carrying heavy logs, security officers and guards, barber, training of dogs, president, working in the butchery, playing with guitar, trumpet and whistle are presented in a masculine form. It is interesting to note that while males are presented carrying luggage with bicycles and carts, females are using their heads. In all the ECE books analysed, majority of the teachers and nurses are depicted as females, while mothers are particularly presented busy with domestic chores such as, bathing babies and cooking. Such masculine and feminine roles are similar with what was reported by Malova (2012); Toci and Aliu, (2013); Jaber (2014); Jabeen et al. (2014); Mustapha (2016). In addition, Foulds (2009); Malova (2012) stated that such gender roles are a reflection of how females continue to be marginalised in the society, an aspect of a male dominated culture.

The under representation of females and girls in masculine related activities could limit their participation and achievement especially in science/technology related courses and careers (Blumberg \& Kenan 2015), which could undermine the achievement of national goals of education (unity and equality) and Kenya's Vision 2030 (social pillar). This is because pupils tend to identify with characters or images of their respective gender as portrayed in the books (Mburu \& Nyaga 2012; Toci \& Aliu 2013), which is likely to have a negative impact on children. The idea of boys engaged in such activities as washing and hanging clothes is similar to Yang's (2012) findings, where males were seen to be sharing household responsibilities with females and girls at home. Further, the presentation of female as pharmacist in the English language books, is a step toward making the books more gender sensitive. It is notable that the content/pictures/illustrations in Tip Top (S) and Little Birds (L) books are gender blind. Although the gender of authors is likely to contribute towards making the book gender responsiveness like was the case with D5 (S), what matters most is whether the authors have the knowledge and skills to write gender friendly materials.

\section{Conclusion and Recommendations}

Findings from the current study reveal portrayal of gender stereotype messages and blind materials in ECE, yet it well documented that preschool years remain a critical period for the growth and development of children. Gender sensitive books enable boys and girls to construct balanced pictures of their gender identity and get equal opportunities to reach their full human potential (Parham, 2013). Thus, as Tantengco (2014) noted, there is need for authors to make curriculum materials gender sensitive or balanced as opposed to being gender blind, a way of empowering girls to enable them to compete favourably with boys for 
similar opportunities in life, while sensitising boys to participate in roles perceived to be for girls. Researchers should continue to challenge gender stereotype materials to ensure the aspirations of boys and girls are not limited by traditional ideas, attitudes and roles in regard to what each of them can do in life. Since the study used 10 ECE supplementary and course books, it is not possible to generalise findings, therefore, researchers should analyse other ECE books and materials using for instance, linguistic categories like nouns, adjectives, pronouns; explore the effect of gender stereotype messages on the participation and performance of girls and boys in different activities. Such a research would be appropriate especially currently (2018) when the new curriculum reforms, the 2:6:6:3 system of education is being implemented in Kenya.

\section{Acknowledgement}

The study was financed by Deans' Committee Research Grant, University of Nairobi.

\section{References}

Abril, P., Cremers, M., Duncan, N., Golubevaite, L., Krabel, J., Lilaite, A., Nordfjell, O. B., Raudonyte, J., \& Romero, A. (2008). Gender Loops: Toolbox for Gender Conscious and Equitable Early Childhood Centres, Hinkelsteinsteindruck sozialistische GmbH, Berlin, Germany. Retrieved from http://docplayer.net/7856758-Gender-loops-toolbox-for-gender-conscious-and-equitable-early -childhood-centres.html (26/10/2017)

Aikman, S., \& Rao, N. (2010). Quality Education for Gender Equality: Background Paper for the Quality Education Stream E4 Conference. New York: UNGEI. Retrieved from http://www.e4conference.org (24/9/2017)

Blumberg, R. L., \& Kenan, W. R. (2015). Eliminating Gender Bias in Textbooks: Pushing for Policy Reforms that Promote Gender Equality in Education. Background Paper Commissioned for EFA Global Monitoring Report 2015, EFA 2000-2015: Achievements and Challenges, UNESCO Paris. Retrieved from https://www.rosadoc.be/digidocs/dd000659_2015_Eliminating_gender_bias_in_textbooks_po licy_reform.pdf (19/1/2018)

Brugeilles, C., \& Cromer, S. (2009). Promoting Gender Equality through Textbooks, A Methodological Guide. UNESCO, Paris. Retrieved from http://unesdoc.unesco.org/images/0015/001588/158897E.pdf (24/10/2017)

Esplen, E. (2009). Gender and Care: Gender and Development, In Brief. Bridge Bulletin, (20). Retrieved http://www.bridge.ids.ac.uk/sites/bridge.ids.ac.uk/files/Docs/InBrief20_care.pdf (19/8/2017)

Foulds, K. (2009). Whose Gender? Exploring Representations in Kenyan Social Studies Textbooks. Thinking Gender Papers, UCLA Centre for the Study of Women, University of California, California, USA. Retrieved from https://escholarship.org/uc/item/79q7k0s 1

Fousiya, P., \& Musthafa, M. A. (2016). Gender bias in school curriculum curbs girls career 
aspirations, IOSR. Journal of Humanities and Social Science (IOSR-JHSS), 21(3), 19-22. Retrieved from http://www.iosrjournals.org/iosr-jhss/papers/Vol.\%2021\%20Issue3/Version-4/D2103041922.p df

Gachara, R. M. (2012). Gender Analysis of Literature Set Books: A Study of Selected Kenya Certificate of Secondary Education (KCSE) Literature Texts. Unpublished PhD Thesis, Kenyatta University.

Gee, B., \& Gee, J. (2005). Seeing Learning in Traditional Classroom Settings. Great Britain: Cromwell Press.

Goble, P., Martin, C., Hanish, L., \& Fabes, R. (2012). Children's gender-typed activity choices across preschool social contexts. Sex Roles, 67, 435-451. https://doi.org/10.1007/s11199-012-0176-9

Huntington, A. S. (2013). Breaking Gender Bias in Early Childhood Education: An Exploration of the Reggio Emilia and Montessori Approaches. Loyola University Chicago School of Law, Comparative Education Law and Policy: Early Childhood Education. Retrieved from https://www.luc.edu/media/lucedu/law/centers/childlaw/earlyeducation/2013studentpapers/hu ntington.pdf

Jabeen, S., Chaudhary, A. Q., \& Omar, S. (2014). Gender discrimination in curriculum: A reflection from Punjab Textbook Board. Bulletin of Education and Research, 36(1), 55-77. Retrieved from http://www.pu.edu.pk/images/journal/ier/PDFFILES/4_Jabeen,\%20Qayyum\%20\&\%20Omar _V36-no1-2014.pdf

Jaber, A. M. (2014). Breaking through Glass Doors: A Gender Analysis of Womenomics in the Jordanian National Curriculum. Working Papers from the 2014 Echidna Global Scholars, Centre for Universal Education, Brookings Institution, Washington DC. Retrieved from https://www.brookings.edu/wp-content/uploads/2016/06/EchidnaAbu-Jaber2014Web.pdf

Kabira, W. M., \& Masinjila, M. (1997). ABC of Gender Analysis Model. FAWE, Nairobi, Kenya.

Karniol, R. (2011). The colour of children's gender stereotypes. Sex Roles, 65, 119-132. https://doi.org/10.1007/s11199-011-9989-1

Kendall, N. (2008). Achieving our Goals and Transforming our Schools: Best practices in the Malawi Teacher Training Activity, USAID. Retrieved from http://miskewitt.com/assets/achieving-our-goals-and-transforming-our-schools.pdf

Kobia, J. M. (2009). Femininity and masculinity in English primary school textbooks in Kenya. The International Journal of Language Society and Culture, 28, 57-71.

Levtov, R. (2014). Addressing Gender Inequalities in Curriculum and Education: Review of Literature and Promising Practices to Inform Education Reform Initiatives in Thailand. 


\section{$\triangle$ Macrothink}

Global Journal of Educational Studies ISSN 2377-3936

Gender Equality and Development, Women's Voice and Agency Research Series 2014, No. 9, World BankReport. Retrieved from http://documents.worldbank.org/curated/en/833731468118462380/pdf/927630NWP0Wome0 0Box385358B00PUBLIC0.pdf

Malova, C. N. (2012). Portrayal of Gender Roles in Kenyan Secondary School Textbooks: An Ethnographic View with Special Reference to English. Unpublished MA Project, University of Nairobi, Kenya.

Mathuri, P. N., Ireri, A. M., Mukumi, D. M., Njagi, A. M., \& Karugu, N. I. (2012). Analysis of gender displays in selected children's books in Kenya. International Journal of Arts, 2(5), 31-38. https://doi.org/10.5923/j.arts.20120205.01

Mattu, A., \& Hussain, H. (2004). Gender Biases and Stereotypes in School Texts. In Human Rights Education in Asian Schools, Vol. VII, Asia-Pacific Human Rights Information Centre, Chikko, Minato-Ku, Japan.

Mburu, D. N. P., \& Nyagah, G. (2012). Effects of gender role portrayal in textbooks in Kenyan primary schools on pupils academic aspirations. Problems of Education in the Century, 47.

Ministry of Education Science \& Technology. (2016). Approved List of School Textbooks and other Instructional Materials for ECDE (15th ed., Vol. 1). Primary Schools and Teacher Training Colleges.

Mirza, M. (2006). Gender Analysis of School Curriculum and Text Books UNESCO. Islamabad, Pakistan. Retrieved from http://unesco.org.pk/education/documents/publications/Gender\%20Analysis $\% 20$ of\%20Schoo 1\%20Curriculum\%20and\%20Text\%20Books.pdf

Miske, S. (2013). Exploring the Gendered Dimensions of Teaching and Learning. Background Paper for the Education for All and Global Monitoring Report, United Nations Girls Initiative, Working Paper, No. 06, New York, USA. Retrieved from http://www.ungei.org/files/Working_Paper_2014.02_(Gender_Dimensions)_FINAL.pdf

Mustapha, A. S. (2012). Dynamics of gender representation in learning materials. Multidisciplinary Journal of Gender Studies, 1(3), 243-270.

Obura, A. (1991). Changing Images: Portrayal of Girls and Women in Kenyan Textbooks. ACTS, Nairobi.

Parham, F. (2013). Gender representation in children's EFL textbooks. Theory and Practice in Language Studies, 3(9), 1674-1679. https://doi.org/10.4304/tpls.3.9.1674-1679

Plan International. (2013). Girls' Learning: Investigating Classroom Practices that promote Girls' Learning. London: Plan UK. Retrieved from https://plan-international.org/publications/girls-learning-investigating-classroom-practices-pr omote-girls-learning\#download-options 
Republic of Kenya. (2007). Gender Policy in Education. Nairobi, Kenya.

Republic of Kenya. (2013). Report of Task Force on the Realignment of Education to 2010 Kenya Constitution. Nairobi, Kenya.

Samadikhah, M., \& Shahrokhi, M. (2015). A critical discourse analysis of ELT materials in gender representation: A comparison of Summit and Top Notch. English Language Teaching, 8(1), 121-133. Retrieved from https://files.eric.ed.gov/fulltext/EJ1075182.pdf

Tantengco, N. S. (2014). Assessment of gender equality in the secondary social studies. Standard Global Journal of Educational Research, 1(3), 062-071.

Toci, A., \& Aliu, M. (2013). Gender stereotypes in current children's English books in elementary schools in the Republic of Macedonia. American International Journal of Contemporary Research, 3(12), 32-38. Retrieved from http://www.aijcrnet.com/journals/Vol_3_No_12_December_2013/6.pdf

UNESCO. (2000). Dakar Framework for Action, Adopted by the World Education Forum. Dakar, Senegal, 26-28 April, 2000. Retrieved from http://unesdoc.unesco.org/images/0012/001211/121147e.pdf

UNESCO. (2015). Education for All Global Monitoring Report. Paris: UNESCO. Retrieved from http://unesdoc.unesco.org/images/0023/002322/232205e.pdf

United Nations. (1979). The Convention on the Elimination of all Forms of Discrimination against Women. New York, USA. Retrieved from http://www.ohchr.org/Documents/ProfessionalInterest/cedaw.pdf

United Nations. (1989). The Convention on the Rights of the Child. New York, USA. Retrieved from https://www.unicef.org/crc/

United Nations. (1995). The Fourth World Conference on Women, Beijing Declaration and Platform for Action, Beijing, China. Retrieved from http://www.un.org/womenwatch/daw/beijing/official.htm

Winthrop, R., \& McGivney, E. (2014). Raising the Global Ambition for Girls Education. The Brookings Institution, Washington, DC 20036. Retrieved from https://www.brookings.edu/research/raising-the-global-ambition-for-girls-education/

Yang, C. C. R. (2012). Is gender stereotyping still an issue? An analysis of Hong Kong Primary English textbook series. Hong Kong Journal of Applied Linguistics, 13(2), 32-48. Retrieved from https://files.eric.ed.gov/fulltext/ED545382.pdf

\section{Copyright Disclaimer}

Copyright for this article is retained by the author(s), with first publication rights granted to the journal.

This is an open-access article distributed under the terms and conditions of the Creative Commons Attribution license (http://creativecommons.org/licenses/by/3.0/). 